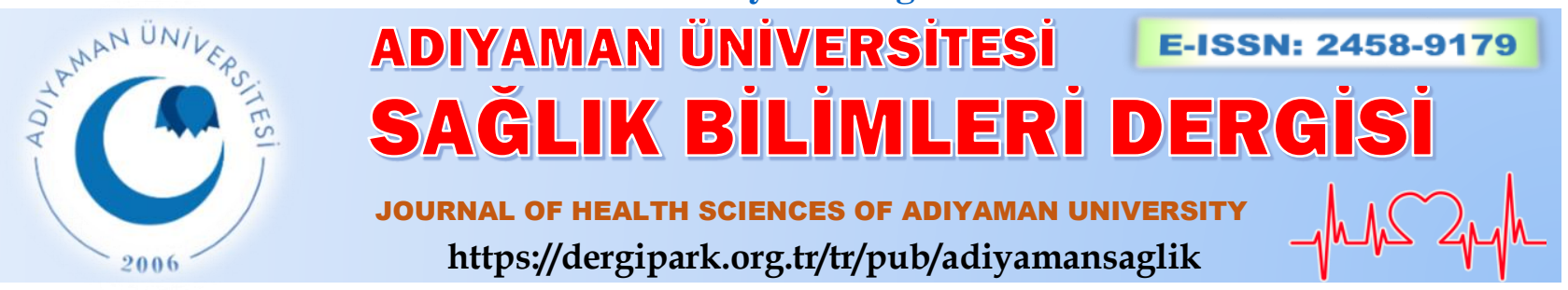

Özgün Araştırma/Research Article

\title{
Yoğun bakımda yatan hastaların deneyimleri ve aile gereksinimlerinin incelenmesi
}

\section{Examination of family needs and experiences of patients in intensive care unit}

\author{
Elif KARAHAN ${ }^{1 @(D)}$, Neslihan AKIN $^{2}$ (D) Sevim ÇELIK ${ }^{3}$ (D) \\ ${ }^{1}$ Zonguldak Bülent Ecevit Üniversitesi, Sağlık Bilimleri Fakültesi, Hemşirelik Bölümü, 67600, Zonguldak-Türkiye \\ ${ }^{2}$ Zonguldak Çaycuma Devlet Hastanesi, Yoğun Bakım Ünitesi, 67900, Zonguldak-Türkiye \\ ${ }^{3}$ Bartın Üniversitesi, Sağlık Bilimleri Fakültesi, Hemşirelik Bölümü, 74100, Bartın-Türkiye
}

Atıf gösterme/Cite this article as: Karahan E, Akın N, Çelik S. Yoğun bakımda yatan hastaların deneyimleri ve aile gereksinimlerinin incelenmesi. ADYÜ Sağllk Bilimleri Derg. 2020;6(2):140-149. doi:10.30569.adiyamansaglik.710495

\section{Öz}

Amaç: $\mathrm{Bu}$ araştırma, yoğun bakım ünitesinde yatan hastaların deneyimleri ve aile gereksinimlerinin belirlenmesi amacıyla kesitsel, tanımlayıcı olarak gerçekleştirildi.

Gereç ve Yöntem: Örneklemi yoğun bakımda en az 24 saat tedavi ve bakım hizmeti aldıktan sonra taburcu olan ya da servise nakledilen 100 hasta ve 100 hasta yakını oluşturdu. Verilerin toplanmasında; Hasta Tanıtım Formu, Kişisel Bilgi Formu, Yoğun Bakım Deneyim Ölçeği ve Kritik Bakım Alanların Aile Gereksinimleri Ölçeği kullanıldı.

Bulgular: Hastaların \%66'sının ilk defa yoğun bakıma yatışının olduğu ve hasta yakınlarının \%42'sinin hastanın 1. dereceden yakını olduğu saptandı. Hastaların Yoğun Bakım Deneyim Ölçeği toplam puanın $61,03 \pm 4,64$ ile deneyimlerinin olumlu olduğu belirlendi. Kritik Bakım Alanların Aile Gereksinimleri Ölçeği'ne göre $150,78 \pm 13,31$ puan ile hasta yakınlarının gereksinimleri oldukça önemli olduğu tespit edildi. İki ölçek arasındaki ilişkinin anlamlı olmadığı saptandı $(p>0.05)$.

Sonuç: Yoğun bakımdaki hasta deneyimlerinin ve hasta yakınlarının gereksinimlerinin farklı olduğu sonucuna ulaşıldı. Bütüncül sağlık hizmetinde bu hususlara dikkat edilmesini önermekteyiz.

Anahtar Kelimeler: Yoğun Bakım; Hasta Deneyimi; Aile Gereksinimi; Hemşirelik Bakımı.

\begin{abstract}
Aim: The aim of this study was to determine the experiences and family needs of patients hospitalized in the intensive care unit.

Materials and Methods: The sample consisted of 100 patients and their relatives who received at least 24 hours of treatment and care in intensive care unit. Patient Information Form, Personal Information Form, Intensive Care Experience Scale and Family Needs Scale of Critical Care Patients were used.

Results: It was determined that $66 \%$ of the patients were admitted to the intensive care unit for the first time and $42 \%$ of the patients' relatives were first degree relatives. Intensive Care Experience Scale of the patients with $61.03 \pm 4.64$ total points are positive. The needs of the relatives of the patients were found to be very important with $150.78 \pm 13.31$ points. The relationship between the two scales was not significant $(p>0.05)$.

Conclusion: It was concluded that patient experiences in intensive care and the needs of patients' relatives are different. We suggest paying attention to these issues in holistic health care.

Keywords: Intensive Care; Patient Experience; Family Needs; Nursing Care.
\end{abstract}

Yazışma Adresi/Address for Correspondence: Elif KARAHAN, Zonguldak Bülent Ecevit Üniversitesi Sağlık Bilimleri Fakültesi, Hemşirelik Bölümü, Esenköy, Kozlu, 67600, Zonguldak-Türkiye, E-mail: elifim67@yahoo.com

Geliş Tarihi/Received:28.03.2020 Kabul Tarihi/Accepted:25.04.2020 Yayım Tarihi/Published online:30.08.2020 


\section{Giriş}

Yoğun bakım üniteleri; ciddi hayati tehlikesi olan, sürekli takip gerektiren ve yaşamı destekleyici tedaviye bağımlı olan hastaların yaşamını sürdürmek; bununla birlikte hasta ve yakınlarını fiziksel, psikolojik ve sosyal olarak desteklemek ve hastalarin olumlu deneyimlerle taburcu olmasını sağlamak amacına yönelik hizmet veren birimlerdir. ${ }^{1-3}$ Yoğun bakım ünitelerinde hastalar hem fiziksel hem de psikososyal açıdan birçok stresörle karşılaşırlar. Hastaların yaşadığ 1 stres ve buna bağlı oluşan rahatsızlıklar bireyin sağlığ üzerinde olumsuz etki göstermekte, iyileşme sürecini uzatmakta ve hastanede kalış süresini artırmaktadır. $^{2-4}$ Hastaların yoğun bakım ünitesinde bulundukları süre boyunca karşılaştıkları olumsuz deneyimlerin; taburcu olduktan sonra, anksiyete, depresyon, öfke, güçsüzlük, spiritüel sıkıntı, uyku yoksunluğu ve strese neden olduğu ve bu durumun yaşamlarını olumsuz etkilediği bildirilmektedir. ${ }^{5-7}$

Çoğu literatürde hastaların fiziksel, fizyolojik ve çevresel stresörlere bağlı olarak yoğun bakım ile ilgili olumsuz deneyim yaşadıklarını göstermektedir., ${ }^{4,8}$ Yoğun bakımda alması gerekli olan tedavi ve bakım, yatağa bağımlı olma, güçsüzlük, uzun süre aynı pozisyonda kalma, gece-gündüz ayırımının kaybedilmesi ve uyku düzenindeki değişim, susuzluk, ağrı, izolasyon, alışık olunmayan çevre ve kişiler, aile üyelerini ve yakınlarını görememe, yalnızlık duygusu, araçlara ve yoğun bakım ünitesine bağımlılık duygusu, sağlık durumu, tedavi ve girişimler hakkında yeterince bilgilendirilmeme gibi nedenlerden dolayı hastalar psikolojik olarak olumsuz etkilenmektedirler. ${ }^{4,6,9,10}$ Yoğun bakımdaki çevresel ve fiziksel etmenlerin yanı sıra, sağlık çalışanlarının hastalara karşı gösterdikleri tutum ve davranışlar doğrudan ya da dolaylı olarak yoğun bakım deneyimini olumlu ya da olumsuz etkileyebilmektedir. ${ }^{10}$

Bütüncül sağlık hizmeti için, hasta kadar hasta aile üyelerinin de gereksinimlerinin karşılanması hemşirelik hizmetlerindeki bakımın kalitesini yükselten bir uygulamadır. Sağlık personelince verilen tedavi ve bakım hizmetlerinde aile üyelerinin gereksinimlerine çok az yer verildiği ya da hiç yer verilmediği gözlenmektedir. ${ }^{5,8}$ Yoğun bakım ünitelerinde doğal olarak tüm ilgi hasta ve hatta hastalık üzerinde yoğunlaşmaktadır. Ancak bu esnada ünitenin kapısının dışında bekleyen aile ile içerideki hasta arasında yaşanan, korku, endişe, merak vb. duygular göz önüne alınmayıp, aile sadece hasta için gerekli bazı malzemelerin tedarik edilmesi veya evrak kayıt gibi işlemlerin yürütülmesini yapan kişiler olarak görülmektedir. ${ }^{8,11}$

Yoğun bakıma kabul genellikle plansız olur ve hastaların kritik bir durumda olduğu kabul edilir. Hasta yakınları içinde sıklıkla bu beklenmedik bir durumdur ve aile sistemini olumsuz yönde etkileyen değişikliklere neden olur. ${ }^{3,12}$ Yüksek ölüm oranı bilinen yoğun bakım ünitesine kabul edilen hastaların aile üyeleri; hastanın durumunun kritik olması, hastalık gidişatının belirsiz olması, hastaları hakkında yeterli bilgiye ulaşamama, personelin olumsuz davranışları, uygulanan tedavinin bilinmemesi, yoğun bakım ünitesindeki çevre ve karmaşık ekipmanlar ve yoğun bakıma yabancı olma gibi nedenlerle korku, endişe, fiziksel ve ruhsal yorgunluk, umutsuzluk, hayal kırıklığ gibi stres ve anksiyete belirtilerini içeren kriz dönemi ile karşı karşıya kalırlar. ${ }^{12-14}$ Çalışmalar ailenin psikolojik rolünün, hastanın fizyolojik durumunu pozitif yönde etkileyerek iyileşmesini ve uzun süreli uyumunu kolaylaştırdığını göstermektedir. ${ }^{8}$

İdeal bir sağlık bakımının sürdürülmesi için hasta ve ailesi bir bütün olarak ele alınmalıdır. Çünkü hasta aile biriminin bir parçasıdır ve bütüncül bakıma ulaşılacak ise hasta ve hasta yakınları için kaliteli sağlık hizmeti vermek zorunludur. ${ }^{15} \mathrm{Bu}$ bağlamda, yoğun bakım hasta deneyimlerinin ve aile gereksinimlerinin birlikte ele alınarak sorunların tespiti ve çözüm önerilerinin belirlenmesi sunulan sağlı hizmetinin kalitesinin arttırılmasında oldukça önemlidir.

$\mathrm{Bu}$ araştırmanın amacı yoğun bakımda yatan hastaların deneyimlerini ve hasta yakınlarının gereksinimlerini belirlemektir.

\section{Gereç ve Yöntem}

Araştırmanın tipi 
$\mathrm{Bu}$ araştırma tanımlayıcı ve kesitsel tipte gerçekleştirildi.

\section{Evren ve örneklem}

Araştırmanın evrenini, Nisan 2016- Ekim 2018 tarihleri arasında Batı Karadeniz Bölgesi'nde yer alan bir devlet hastanesinin dahili, cerrahi ve koroner yoğun bakım ünitelerinde yatan hastalar ve onların yakınları oluşturdu. Örneklem kapasitesini belirlemede Demir ve ark. araştırmass ${ }^{7}$ temel alınarak, \%5 kabul edilebilir hata oranı ve \%90 güven aralığında önerilen örneklem büyüklüğü 100 olarak hesapland. Araştırmada herhangi bir örnekleme yöntemine gidilmemiş olup; yoğun bakım ünitelerinde en az 24 saat tedavi ve bakım hizmeti aldiktan sonra taburcu olan ya da servise nakil edilen, iletişim kurulabilen, 18 yaş üstü, kendi rızası ile araştırmaya katılmayı kabul eden 100 hasta ve 100 hasta yakın örneklemi oluşturdu. Araştırmanın dışlanma kriterleri; yoğun bakım ünitesinde 24 saatten daha az tedavi ve bakım alma, 18 yaş altı olma, iletişim kurulamama ve araştırmaya katılmak istememedir.

\section{Veri toplama araçları}

Araştırma verilerinin toplanmasında; hastalar için Hasta Tanıtım Formu ve Yoğun Bakım Deneyim Ölçeği (YBDÖ), hasta yakınları için Kişisel Bilgi Formu ve Kritik Bakım Alanların Aile Gereksinimleri Ölçeği kullanıld1. İlgili literatür doğrultusunda ${ }^{1-4,6}$ oluşturulan Hasta Tanıtım Formu'nda hastaların demografik ve klinik bilgileri içeren 12 soru yer aldı. Benzer şekilde ilgili literatür doğrultusunda ${ }^{5,8,15}$ hasta yakınları için oluşturulan Kişisel Bilgi Formu'nda demografik ve hasta bakımında üstlendikleri rollere yönelik 12 soru yer ald.

\section{Yoğun bakım deneyim ölçeği}

Rattray ve ark. tarafindan 2004 yılında yoğun bakımda yatan hastaların yaşadıkları deneyimleri değerlendirmek amacıyla geliştirilmiştir. YBDÖ’nin Türkçe geçerlik ve güvenirlik çalışması Demir ve ark. tarafından 2009 yılında yapılmıştır. ${ }^{7}$ Ölçek 5'li likert tipli, toplam 19 maddeden oluşmaktadır. Ölçekte hastanın yoğun bakıma olan uyumunu değerlendiren 9 maddesi; 1-
Kesinlikle Kat1liyorum (5 puan), 2Katıliyorum (4 puan), 3-Kararsızım (3 puan), 4-Katılmiyorum (2 puan), 5-Kesinlikle Katılmiyorum (1 puan) şeklinde değerlendirilmektedir. Hastanın yaşadığı emosyonel durumun sıklığını belirleyen diğer 10 madde ise 1- Her zaman (5 puan), 2- Çoğu zaman (4 puan), 3- Bazen (3 puan), 4Nadiren (2 puan), 5- Hiçbir zaman (1 puan) şeklinde değerlendirilmektedir. Ölçeğin "çevrenin farkında olma, yoğun bakımda yaşanan kötümser deneyimler, yoğun bakımda yaşanan deneyimlerin hatırlanması ve yoğun bakımda alınan bakımdan memnuniyet" şeklinde 4 alt boyutu vardır. Ölçekten en az alınacak puan 19 en fazla ise 95'dir. Ölçekten alınan toplam puan artıkça hastanın yaşadığı deneyimin olumlu olduğu şeklinde değerlendirilmektedir. Ölçeğin Cronbach alfa katsayıs1 $0.79^{\prime}$ dur. $^{7} \mathrm{Bu}$ araştırmada toplam madde Cronbach alfa katsayıs1 0.78 olarak hesapland1.

\section{Kritik bakım alanların aile gereksinimleri ölçeği}

1979 yılında Molter tarafından geliştirilen ölçek 1984 yılında Daley tarafindan beş alt gruba ayrılmıştır. 1998 yılında Ünver'in yaptığı Türkçe geçerlilik ve güvenirlik çalışması sonucunda ölçek 46 maddeden oluşmaktadır. Her madde için 1-4 puanlık likert tipi derecelendirme yapılmaktadır. Buna göre; hiç önemli değil (1 puan), az önemli (2 puan), oldukça önemli (3 puan), çok önemli (4 puan) şeklindedir. Alınan puanlar arttıkça gereksinim düzeyinin arttığını göstermektedir. Toplam ölçek puanı en az 46 en fazla 184'dür. Ölçeğin Cronbach alfa katsayısı 0.82 'dir. ${ }^{11} \mathrm{Bu}$ araştırmada toplam madde Cronbach alfa katsayısı 0.89 olarak hesapland1.

\section{Verilerin toplanması}

Veriler aynı araştırmacı tarafından yüz yüze görüşme tekniği ile toplandı. Hasta ve hasta yakını ile görüşmeler ayrı ayrı olarak sessiz bir ortamda yapıld1. Hastalar ile yapilan görüşme hastanın durumuna uygun olarak ya yoğun bakım ünitesinde ya da serviste hasta odasında yapıldı. Bu görüşme yaklaşı 10 dakika sürdü. Hasta yakınları ile yapılan görüşme ziyaretçi odasında yapıldı ve 
yaklaşık 20 dakika sürdü.

\section{Verilerin analizi}

Verilerin analizinde International Business Machines Corporation Statistical Package for Social Science (IBM SPSS) statistics for Windows, 19.0 (IBM Corp., Armonk, NY, USA) programı kullanıldı. Araştırma verileri değerlendirilirken tanımlayıcı istatistiksel metotlar (ortalama, standart sapma, medyan, minimum, maksimum) kullanıldı. Nicel verilerin normal dağılıma uygunlukları Shapiro-Wilk testi ve grafiksel incelemeler ile sınand. Nicel değişkenler arası ilişkilerin değerlendirilmesinde Spearman korelasyon analizi kullanıldı. İstatistiksel anlamlılık $p<0,05$ olarak kabul edildi.

\section{Araştırmanın etik boyutu}

Araştırmanın yapıldığ 1 ilde bulunan üniversitenin İnsan Araştırmaları Etik Kurulu'ndan etik izin (Tarih:21.04.2016, Protokol No:117), ölçeklerin kullanımı için yazarlardan elektronik posta yoluyla yazılı izin ve kurumdan yazılı izin alındı. Araştırma Helsinki Bildirgesi ilkelerine göre yürütüldü. Hasta ve hasta yakınlarının araştırma hakkında açıklama yapılarak bilgilendirilmiş onamları yazılı olarak alındı.

\section{Bulgular}

$\mathrm{Bu}$ araştırmanın örneklemini oluşturan hastaların \%51'inin erkek, \%71'inin evli, \%35'inin 46-65 yaş aralığında, \%64'ünün okur-yazar olmadiğ 1 belirlendi. Hastaların klinik özellikleri değerlendirildiğinde $\% 56$ 'sının cerrahi yoğun bakımda tedavi aldığı, \%66'sının ilk defa yoğun bakıma yatışının olduğu ve \%73'ünün 2-8 gün yoğun bakımda yatarak tedavi aldığı saptandı (Tablo 1).

Hasta yakınlarının tanımlayıcı özellikleri değerlendirildiğinde; \%76'sının kadın, \%85'inin evli, \%52'sinin 18-45 yaş aralığında, \%46'sının ilk öğretim mezunu olduğu, \%64'ünün ev hanımı ve \%43'ünün bir çocuğa sahip olduğu tespit edildi. Hasta yakınlarının hastaya olan yakınlık durumu incelendiğinde $\% 42$ 'sinin 1 . derece yakını, \%33'ünün eşleri olduğu, \%75'inin daha önce refakatçilik deneyimi olduğu ve \%54'ünün 1-
5 gün arasında refakatçilik yaptığı belirlendi (Tablo 1).

Hastaların yoğun bakımda tedavi aldıkları süreç içerisinde yaşadıkları deneyimler YBDÖ’ne göre değerlendirildi. Ölçek alt boyutlarının ortalaması şu şekildedir; çevrenin farkında olma $22,73 \pm 2,76$, yaşanan kötümser deneyimler 9,33 $\pm 1,21$, deneyimlerin hatırlanmas1 $13,89 \pm 1,56$, alınan bakımdan memnuniyet $15,08 \pm 1,67$ 'dir. Ölçek toplam puanı 61,03 $\pm 4,64$ 'dür (Tablo 2).

Hastaların cinsiyet, yaş grupları, yatışın olduğu yoğun bakım ünitesi ve yoğun bakımda yatış süresine göre YBDÖ ve alt boyutları karşılaştırması yapıldı. Cinsiyete göre YBDÖ ve alt boyutları arasında anlamlı fark saptanmadi $(p>0,05)$. Yaş değişkenine göre 18-45 yaş grubunda çevrenin farkında olma alt boyutunda $\left(\chi_{K-W}^{2}=9,53 ; p=0,02\right)$; yoğun bakımda yaşanan deneyimlerin hatırlanmasi alt boyutunda $\left(\chi^{2} K-W=7,42\right.$; $p=0,06)$ ve ölçek toplam puanında $\left(\chi^{2}{ }_{K}\right.$ $w=15,07 ; \quad p=0,002)$ anlaml olarak puanın daha yüksek olduğu, yoğun bakımda yaşanan kötümser deneyimler alt boyutunda ise 46-65 yaş grubunda $\left(\chi^{2} K-W=17,64 ; p=0,001\right)$ anlamlı olarak puanın daha az olduğu belirlendi. Yoğun bakımda 1 gün yatışı olan hastaların çevrenin farkında olma $\left(\chi^{2}{ }_{K-W}=25.42\right.$; $p=0,000)$, yoğun bakımda yaşanan deneyimlerin hatırlanmasi $\quad\left(\chi^{2} K-W=13,28\right.$, $p=0,001)$ ve ölçek toplam puanında $\left(\chi^{2}\right.$ $w=23,27, p=0,000)$ anlamlı olarak puanlarının yüksek olduğu saptandı. Hastaların tedavi aldıkları yoğun bakım ünitelerine göre ölçek puan ortalamaları karşılaştırıldığında; dahiliye yoğun bakımda yatan hastaların çevrenin farkinda olma alt boyutunda $\left(\chi^{2}{ }_{K-W}=7,31\right.$, $p=0,02)$; yoğun bakımda yaşanan kötümser deneyimler alt boyutunda $\left(\chi^{2}{ }_{K-W}=16,79\right.$, $p=0,000)$ ve ölçek toplam puanında $\left(\chi^{2} K\right.$ $w=8,85, p=0,01)$ anlamlı olarak puanlarının düşük olduğu saptand1.

Hasta yakınlarının gereksinimleri Kritik Bakım Alanların Aile Gereksinimleri Ölçeği'ne göre değerlendirildiğinde; puan aralığının 128 ile 172 arasında değiştiği, ortalama ise $150,78 \pm 13,31$ puan olduğu görüldü (Tablo 2). 
Tablo 1. Hasta ve hasta yakınlarının tanıtıcı özellikleri.

\begin{tabular}{|c|c|c|c|}
\hline Özellikler & & Hasta & Hasta Yakını \\
\hline Kadın/Erkek \% & & $49 / 51$ & $76 / 24$ \\
\hline Evli/Bekar \% & & $71 / 29$ & $85 / 15$ \\
\hline \multirow[t]{4}{*}{ Yaş grubu \% } & $18-45$ & 14 & 52 \\
\hline & $46-65$ & 35 & 48 \\
\hline & $66-75$ & 31 & - \\
\hline & 76 ve üstü & 20 & - \\
\hline \multirow[t]{4}{*}{ Eğitim Durumu \% } & Okur-yazar değil & 64 & 12 \\
\hline & İlk öğretim & 28 & 46 \\
\hline & Lise & 8 & 32 \\
\hline & Üniversite & - & 10 \\
\hline \multirow[t]{3}{*}{ Uğraşı Durumu \% } & Ev hanımı & 44 & 64 \\
\hline & Çalışıyor & 4 & 23 \\
\hline & Çalışmıyor & 52 & 13 \\
\hline \multirow[t]{2}{*}{ Yaşadığ1 Yer \% } & İl-ilçe & 42 & 54 \\
\hline & Köy & 58 & 46 \\
\hline \multirow[t]{3}{*}{ Gelir-gider Durumu \% } & Birbirine denk & 12 & 33 \\
\hline & Kısmen yeterli & 71 & 63 \\
\hline & Yetersiz & 17 & 4 \\
\hline \multirow[t]{3}{*}{ Çocuk Sayısı \% } & 1 çocuk & 16 & 43 \\
\hline & 2 çocuk & 39 & 37 \\
\hline & 3 ve üzeri & 45 & 20 \\
\hline Sosyal Güvence \% & Var / Yok & $100 /-$ & $86 / 14$ \\
\hline \multirow[t]{3}{*}{ Yoğun Bakım Ünitesi \% } & Dahili Yoğun Bakım & 22 & \\
\hline & Cerrahi Yoğun Bakım & 56 & \\
\hline & Koroner Yoğun Bakım & 22 & \\
\hline \multirow{3}{*}{$\begin{array}{l}\text { YBÜ'de Yatılan Gün Sayısı } \\
\%\end{array}$} & 1 gün & 17 & \\
\hline & $2-8$ gün & 73 & \\
\hline & 9-20 gün & 10 & \\
\hline \multirow[t]{3}{*}{ YBÜ’ne Yatış Sayısı \% } & İlk yatış & 66 & \\
\hline & 2. yatış & 15 & \\
\hline & 3 ve üzeri & 19 & \\
\hline \multirow[t]{3}{*}{ Yakınlık Durumu \% } & Eş & & 33 \\
\hline & 1.Derece akraba & & 42 \\
\hline & 2.Derece akraba & & 25 \\
\hline Refakatçilik Deneyimi \% & Var/Yok & & $75 / 25$ \\
\hline \multirow[t]{3}{*}{ Refakatçilik Süresi \% } & $1-5$ gün & & 54 \\
\hline & 6-10 gün & & 16 \\
\hline & 11 ve üzeri & & 30 \\
\hline
\end{tabular}

Tablo 2. Yoğun bakım deneyim ölçeği ve kritik bakım alanların aile gereksinimleri ölçeği puan ortalamaları.

\begin{tabular}{lccc}
\hline $\begin{array}{l}\text { Yoğun Bakım Deneyim Ölçeği } \\
\text { ve Alt boyutları }\end{array}$ & Madde Sayısı & Min-Max & Ort \pm Ss \\
\hline $\begin{array}{l}\text { Çevrenin Farkında Olma } \\
\text { Yoğun Bakımda Yaşanan }\end{array}$ & 6 & $17-29$ & $22,73 \pm 2,76$ \\
$\begin{array}{l}\text { Kötümser Deneyimler } \\
\text { Yoğun Bakımda Yaşanan }\end{array}$ & 4 & $7-12$ & $9,33 \pm 1,21$ \\
$\begin{array}{l}\text { Deneyimlerin Hatırlanması } \\
\text { Yoğun Bakımda Alınan }\end{array}$ & 4 & $10-17$ & $13,89 \pm 1,56$ \\
$\begin{array}{l}\text { Bakımdan Memnuniyet } \\
\text { Deneyim Toplam Puan }\end{array}$ & 5 & $12-19$ & $15,08 \pm 1,67$ \\
\hline $\begin{array}{l}\text { Kritik Bakım Alanların Aile } \\
\text { Gereksinimleri Ölçeği }\end{array}$ & 19 & $51-69$ & $61,03 \pm 4,64$ \\
\hline
\end{tabular}

Hasta yakınlarının Kritik Bakım Alanların Aile Gereksinimleri Ölçeği’ne göre en önemli 10 gereksinimleri ve en az önemli 10 gereksinimi Tablo 3'de gösterildi. Buna göre hasta yakınları için en önemli gereksinimin hastasının iyileşme şansını bilme, günde bir kez olsun hastanın durumuna ilişkin bilgi verilmesi olduğu belirlendi. En az önem derecesindeki gereksinimin ise ağlamamı cesaretlendirecek birinin olması talebinin yer aldığı görüldü. 
Tablo 3. Kritik Bakım Alanların Aile Gereksinimleri Ölçeğine Göre Gereksinim Önem Sırası

\begin{tabular}{lc}
\hline En Önemli 10 Gereksinim & Ortalama Puan \\
\hline Hastanın iyileşme şansını bilmek & 3,81 \\
Günde bir kez olsun hastanın durumuna ilişkin bilgi verilmesi & 3,77 \\
Hastane personelinin hastayla ilgili olduğunu hissetmek & 3,73 \\
Hastaya en iyi bakımın verildiğinden emin olmak & 3,72 \\
Hastanın nakli ile ilgili planların önceden bildirilmesi & 3,72 \\
Hastada gelişme olduğunu gösteren durumların neler olduğunu bilmek & 3,71 \\
Açıklamaların anlayabileceğim şekilde yapılması & 3,71 \\
Ümidin var olduğunu hissetmek & 3,70 \\
Hastane personeli tarafindan kabul gördüğümü hissetmek & 3,67 \\
Günde bir kez olsun doktorla konuşmak & 3,67 \\
\hline En Az Önemli 10 Gereksinim & Ortalama Puan \\
\hline Hastanedeyken istediğim yiyecekleri bulabilmek & 2,98 \\
Suçluluk ve öfke gibi duygularımı konuşabileceğim birilerinin bulunması & 2,96 \\
İstediğimde yalnız kalabilmek & 2,93 \\
Duygularımı birileriyle konuşmak & 2,91 \\
Yanımda bir din adamı getirebilmem & 2,88 \\
Her gün aynı hemşireyle konuşabilmek & 2,84 \\
Bekleme odasının yakınında telefon olması & 2,52 \\
Hastanede yalnız kalabileceğim bir yer bulmak & 2,42 \\
Hastanedeki din hizmetleri hakkında bilgi verilmesi & 2,01 \\
Ağlamamı cesaretlendirecek birinin olması & 1,66 \\
\hline
\end{tabular}

Araştırmaya katılan hastaların YBDÖ ve alt boyutları ile hasta yakınlarının Kritik Bakım Alanların Aile Gereksinimleri Ölçeğinden

aldıkları puanlar arasındaki ilişkinin istatistiksel olarak anlamlı olmadı̆̆ belirlendi (Tablo $4 ; p>0,05$ ).

Tablo 4. Yoğun bakım deneyim ölçeği ile kritik bakım alanların aile gereksinimleri ölçeği puanları arasındaki ilișkinin değerlendirilmesi

\begin{tabular}{lcc}
\hline Yoğun Bakım Deneyim Ölçeği & Kritik Bakım Alanların Aile Gereksinimleri Ölçeği \\
& $\mathbf{p}^{*}$ & 0,455 \\
Çevrenin Farkında Olma & 0,076 & 0,279 \\
Yoğun Bakımda Yaşanan Kötümser Deneyimler & $-0,109$ & 0,844 \\
Yoğun Bakımda Yaşanan Deneyimlerin & $-0,020$ & 0,810 \\
Hatırlanması & & 0,846 \\
Yoğun Bakımda Alınan Bakımdan Memnuniyet & $-0,024$ & \\
Deneyim Toplam Puan & $-0,020$ &
\end{tabular}

\section{Tartışma}

Dünya nüfusunun yaşlanmasında sağlık hizmetlerinin ulaşılabilirliği önemli bir rol oynamaktadır. Türkiye İstatistik Kurumu verilerine göre Türkiye genelinde, 50 yaşında olan bir kişinin kalan yaşam süresi ortalama 30,7 yıldır. ${ }^{16} \mathrm{Bu}$ araştırmada hastaların büyük çoğunluğunun orta yaş ve yaşlı grubunda olması istatistik verileri ile uyumludur. Sağlık Bakanlığı 2018 verilerine göre 13,651.377 hastanın yatarak tedavi gördüğü ve bunların 5,201.738'ine cerrahi girişim uygulandı ğ 1 görülmektedir. ${ }^{17}$ İleri yaş ve ek hastalıklarla birlikte cerrahi girişim sonrası yoğun bakım ünitesinde kısa süreli takip sik yaşanan bir durumdur. $\mathrm{Bu}$ araştırmada da hastaların ilk defa yoğun bakım tedavisi aldıkları, çoğunluğunun cerrahi yoğun bakıma kabul edildiği ve bir haftaya yakın bir tedavi süreci olduğu tespit edilmiştir. Araştırma örneklemindeki hasta profili, Türkiye sağlik istatistiği verileri ile uyumlu olarak bölgedeki sağlık hizmetinin ulaşılabilirliğini göstermektedir.

$\mathrm{Bu}$ araştırmada hastaların yoğun bakımda aldıkları tedavi sürecinde çevrenin farkında oldukları, deneyimlerinin olumlu ve memnuniyetlerinin yüksek olduğu belirlenmiştir. Buna karşın kötümser deneyimler yaşadıkları da tespit edilmiştir. Araştırmada hastaların ölçek toplam puanına göre yoğun bakım deneyimlerinin olumlu olduğu sonucuna varılmıştır. Ülkemizde yaklaşık 20 yıl öncesinde yapılan araştırma sonuçlarında da, güncel araştırma sonuçlarında da hastaların yoğun bakım deneyimlerinin çok istendik düzeyde olmadığ 1 görülmektedir. ${ }^{1,4,6,7,18,19}$ Ürdün'de yapılan bir 
araştırmada yoğun bakımdaki hastaların çevrelerine ve yakınlarına farkındalıklarının yüksek olduğu ve aldıkları bakıma yönelik memnuniyet puanlarının düşük olduğu rapor edilmiştir. $^{20}$ Yoğun bakımlar, hastalarının fizyolojik fonksiyonlarının değişiklik göstermesi nedeniyle bu gereksinimlerinin karşılanmasının öncelikli olduğu bununla birlikte psikolojik ve sosyal gereksinimlerinin de önemli ve karşılanması gerekliliği ortaya çıkmaktadır. Ancak yoğun iş yükü gibi nedenlerden dolayı bu gereksinimlerin tam olarak karşılanamadığ belirtilmektedir. $^{10,21}$ $\mathrm{Bu}$ doğrultuda hastaların yoğun bakım deneyimlerinin şekillenmesinde hem hasta kaynaklı hem sistem kaynaklı bir çok faktörün rol oynayabileceği görülmektedir.

Hastaların cinsiyetine göre yoğun bakım deneyimi ve alt boyutları arasinda anlaml fark olmadığ 1 tespit edilmiştir. Literatürde bu araştırma sonucuna paralellik gösteren araştırmalar $^{1,6,10,19,22}$ olmakla birlikte, kadınların erkeklere göre yoğun bakım deneyiminin daha olumlu olduğunu ${ }^{2-4,7}$ ve çevre farkındalıklarının daha yüksek olduğunu $^{23}$ gösteren araştırmalar da bulunmaktadır. Demir ve ark. yaptığ 1 araştırmada erkeklerin daha fazla kötümser deneyim yaşadığ ${ }^{7}$, Alasad ve ark. yaptığ araştırmada $^{20}$ ise kadınların daha fazla kötümser deneyimler yaşadıkları bildirilmiştir. $\mathrm{Bu}$ araştırma ve literatürdeki farklı araştırma sonuçlarına göre cinsiyetin, hastaların yoğun bakım deneyimlerini etkilemediğini göstermektedir.

$\mathrm{Bu}$ araştırmada genç yaştaki hastaların anlamlı olarak çevre farkındalıklarının yüksek olduğu, yaşadıkları deneyimleri hatırlayabildikleri ve yoğun bakım deneyimlerinin daha olumlu olduğu belirlenmiştir. Literatürde yaş değişkenine göre hastaların yoğun bakım deneyimleri arasında farkın olmadığını bildiren araştırmalar olmakla birlikte ${ }^{1,7}$, Çam ve Şahin'in yaptığı araştırmada yaş ile yoğun bakım deneyimi arasında anlamlı ilişki olduğu bildirilmiştir. ${ }^{18} \mathrm{Bu}$ araştırmada $46-65$ yaş grubundaki hastaların da anlamlı olarak kötümser deneyimler yaşadıkları saptanmıştır. Akdemir' in araştırmasında da bu araştırma ile benzer olarak 51 yaş ve üzeri olan hastaların daha fazla kötümser deneyimler yaşadığı bildirilirken $^{22}$, Göktaş ve ark. yaptığı araştırmada 65 yaş ve üzeri hastaların kötü deneyimlerin arttığı ve memnuniyetlerinin de düşük olduğu rapor edilmiştir. ${ }^{23}$ Yaşlanma ile beyinde meydana gelen fizyolojik değişikliklerin bir sonucu olarak kognitif fonksiyonlarda da azalma meydana gelir. $\mathrm{Bu}$ kognitif değişiklik özellikle hafızada 1lımlı azalma ile kendisini gösterir. ${ }^{24}$ Çağlıyan ve Dağ'ın araştırmasında da 61-70 yaş grubundaki hastaların yoğun bakım deneyimi ve deneyimlerin hatırlanması puanlarının anlamlı olarak düşük olduğu bildirilmiştir. ${ }^{19}$ $\mathrm{Bu}$ doğrultuda bu araştırmada olduğu gibi genç hastaların yoğun bakım deneyimlerinin daha olumlu olması beklendik bir sonuçtur.

Yoğun bakımda bir gün yatışı olan hastaların anlamlı olarak çevrenin farkında oldukları, yoğun bakımda yaşanan deneyimleri hatırladıkları ve yoğun bakım deneyimlerinin olumlu olduğu tespit edilmiştir. Sekmen ve Ünsar'ın yaptığı araştırma sonucunda da bu araştırma sonucuna benzer olarak yoğun bakımda 1-5 gün arasında yatan hastaların deneyimlerinin olumlu olduğu bildirilmiştir. ${ }^{25}$ Buna karşın Çağlıyan ve Dağ'ın araştırma sonucunda yatış süresinin yoğun bakım deneyimini etkilemediği rapor edilmiştir. ${ }^{19}$ Literatürde yatış süresinin ve sıklığının artması ile birlikte hastaların kötümser deneyimlerinin de arttığ1 belirtilmektedir. ${ }^{1,7,18,23}$ Yoğun bakımda kısa süreli yatış, tedaviye yanıtın bir göstergesidir. Hastanın yoğun bakımda olumlu deneyimler yaşamasında yatış süresinin azalması ve iyilik halinin sürdürülmesi birer etkendir.

Dahiliye yoğun bakımda yatan hastaların çevrenin farkında olma puan ortalamasının daha düşük, yoğun bakımda yaşanan kötümser deneyimlerinin daha fazla ve yoğun bakım deneyimlerinin olumsuz olduğu belirlenmiştir. Özşaker ve ark. yaptığı araştırma sonucunda da kalp-damar cerrahisi, üroloji ve genel cerrahi yoğun bakım ünitelerinin hastaların yoğun bakımda yaşanılan deneyimlerini, kötümser deneyimleri, deneyimlerinin hatırlanmasını ve bakımdan memnuniyeti anlamlı şekilde etkilediği bildirilmiştir. ${ }^{1}$ Acil ve elektif kardiyak cerrahi geçiren hastaların 
değerlendirildiği bir araştırma sonucuna göre ise; elektif cerrahi geçiren hastaların çevre farkındalığının daha yüksek olduğu ve memnuniyetlerinin de yüksek olduğu, acil cerrahi girişim yapılan hastaların kötü deneyimlerin arttığı ve memnuniyetlerinin de düşük olduğu rapor edilmiştir. ${ }^{23}$ Sekmen ve Ünsar'ın yaptığı araştırma sonucunda girişimsel kardiyoloji işlemi için yatışı yapılmış yoğun bakım hastalarının yoğun bakım deneyimlerinin daha pozitif olduğu bildirilmiştir. ${ }^{25}$ Cerrahi yoğun bakımlarda akut hastalıkların tedavi ve bakımlarının yapıldığı düşünüldüğünde bu hastaların daha hızlı iyileşme beklentisi olumlu deneyimler yaşamasına sebep olabilir. Dahili yoğun bakımlar ise kronik hastalıkların bir yansıması olarak hasta deneyimlerini de olumsuz etkileyebilir.

$\mathrm{Bu}$ araştırmada hasta yakınlarının büyük çoğunluğunun kadın, evli, ev hanımı, 18-45 yaş aralığında ve çocuk sahibi olduğu belirlenmiştir. Hastaya olan yakınlık durumu değerlendirildiğinde ise yarısına yakınında 1 . dereceden akraba olduğu, \%33'ünün eşi olduğu ve büyük çoğunluğunun daha önceden refakatçilik deneyimi olduğu tespit edilmiştir. Türk toplumunun kültürel yapısına bağlı olarak kadın olmak ve evliliğin bireylere getirdiği bir takım rol ve sorumlulukları nedeniyle hastalık durumunda refakatçi olarak hasta ile ilgilenmek beklenilen bir durumdur. $^{25} \mathrm{Bu}$ araştırma sonucu da Türk toplumunun kültürel yapısını yansıtmaktadır.

Hasta yakınlarının gereksinimleri ve gereksinimler arasındaki öncelikler, hastalığın ciddiyetine, bireylerin kültürel farklılıklarına ve hastanın yattığ 1 üniteye göre değişebilmektedir. ${ }^{8}$ Yoğun bakımda tedavi alan hasta yakınlarının gereksinimleri destek, konfor, bilgi alma, yakınlık ve güvence başlıkları altında değerlendirilmektedir. ${ }^{26} \mathrm{Bu}$ araştırmada aile yakınlarının gereksinimlerini belirlemeye yönelik kullanılan ölçekte 46 madde yer almakta ve toplam puanın üst sınırı yakın olması sebebiyle hasta yakınlarının gereksinimlerinin oldukça önemli olduğunu göstermektedir. T1bbi teknolojiler ilerledikçe, hastaların yoğun bakım ünitesinde kaldıkları gün sayısı da artmaktadır. ${ }^{27} \mathrm{Bu}$ nedenle, hemşirelerin hasta yakınlarının kritik bir hastalık durumunda nasıl baş edebildiklerini anlamaları önemlidir.

$\mathrm{Bu}$ araştırmada hasta yakınlarının en önemli gereksinimlerinin "hastasının iyileşme şansını bilme, günde bir kez olsun hastanın durumuna ilişkin bilgi verilmesi" olduğu, en az önem derecesindeki gereksinimin ise "ağlamamı cesaretlendirecek birinin olması" talebinin yer aldığ 1 belirlendi. Bu araştırma sonucu ile benzer olarak Ünver'in yaptığ araştırmada "Günde bir kez olsun hastanın durumuna ilişkin bilgi verilmesi" gereksinimini birinci sırada yer almıştır. ${ }^{11}$ Yoğun bakım ünitesinde yatan hastaların aile üyelerinin ihtiyaçlarına yönelik yapılan araştırmalarda; yaş, cinsiyet, sosyoekonomik durum ve eğitim düzeyi ne olursa olsun ailelerin en önemli ihtiyaçları arasında; "hastalarının durumu ve durumunda meydana gelen değişiklikler hakkında bilgi edinme ile en iyi bakımın hastaya verildiğinden emin olmak" olduğu gösterilmiştir. ${ }^{14}$ Avustralya'da 3. derece yoğun bakım ünitesinde travma hastalarının ailelerinin ihtiyaçlarını belirlemek amacıyla hasta ve hemşirelerin düşüncelerinin değerlendirildiği bir araştırmada, bireysel stres yönetimi, uyum, rehberlik ve bakım gereksinimleri belirlenmiş, ancak hemşirelerin ailelerin gereksinimlerini, onların belirlediği gereksinim düzeyinden daha düşük olduğunu rapor edilmiştir. ${ }^{26}$

Hasta yakınları, diğer sağlık çalışanlarının aksine, stresli durumlarda, hemşirelerin onlara karşı daha yakın olduklarına inanmaktadırlar. Hemşireleri; hastalarını ziyaret edemediklerinde arayacakları, kendi ihtiyaçları ile de ilgilenen kilit sağlık personeli olarak tanımlarlar. Hasta yakınları, sorularının dürüstçe cevaplandırılması; hastayla ilgilenen personellerin kimler olduğunu bilmek; hastane çalışanları tarafindan kabul edildiğini hissetmek ve anlaşılabilir şekilde hastası hakkında bilgi almak isterler. Hemşireler yalnızca çok temel bilgileri açılayabilirler ve genellikle tıbbi terimler kullanmadan bunu yaparlar. Çoğu hasta yakını hemşirelerle iletişim kurmak için kendilerini rahat hissederler. Hasta yakınları tarafindan sayg1 duyulan bir hemşire, onlar için duygusal destek sağlayabilir ve ihtiyaç duyulduğunda kaçınılmaz durumları kabul 
etmelerine yardımc1 olabilir. ${ }^{21,28}$ Yeni Zellanda da yoğun bakımda kalitatif yöntemle hasta ve hasta yakınlarının deneyimlerinin değerlendirildiği bir araştırmada, tedavinin her aşamasında belirsizliğin onlar için egemen olduğu sonucuna varılmıştır. Hemşire bakım verirken onlar için belirsizlik seviyesini algılayabilmeli ve aile merkezli bir yaklaşım sunması gerektiği ifade edilmiştir. ${ }^{27}$ Tutarlı ve eksiksiz bilgi paylaşımı sağlık çalışanı ve hasta yakınları için ortak bir alan olmuştur. ${ }^{15}$ $\mathrm{Bu}$ araştırma sonucunda da hasta yakınlarının hastası hakkında bilgi edinme gereksiniminin öncelikli olması literatür ile uyumlu olduğu görülmüştür.

\section{Sonuç}

$\mathrm{Bu}$ araştırmada hastaların yoğun bakımda aldıkları tedavi sürecinde deneyimlerinin olumlu ve memnuniyetlerinin yüksek olduğu belirlenmiştir. Buna karşın orta yaş grubunda anlamlı olarak kötümser deneyimler yaşandığ da tespit edilmiştir. Hasta yakınları için gereksinimlerinin oldukça önemli olduğu ve en önemli gereksinimin hastasının iyileşme şansını bilme olduğu saptanmıştır. Hasta deneyimleri ile hasta yakınlarının gereksinimleri arasında ilişki olmadığ 1 belirlenmiştir.

Yoğun bakım ünitelerinde tedavi olan hastaların ve yakınlarının tüm fiziksel, ruhsal ve psikososyal gereksinimlerin karşılanması ancak buna yönelik değerlendirmelerin yapılması ve gerekli önlemlerin alınması ile sağlanabilir. $\mathrm{Bu}$ yaklaşım aile merkezli hizmet yaklaşımı ile örtüşmekte ve kaliteli sağlık bakınma alt yapı oluşturmaktadır. $\mathrm{Bu}$ araştırmada hasta deneyimleri ve hasta yakınlarının gereksinimlerine yönelik bir veri sunmaktadır. İyileşme göstergeleri olarak benzer araştırmaların yapılmasını ve klinik ortamlarda saptanan bu sorunlara yönelik kurumsal ya da bireysel çabaların gösterilmesini önermekteyiz.

\section{Araştırmanın Etik Boyutu}

Araştırmanın yapıldığı ilde bulunan üniversitenin İnsan Araştırmaları Etik Kurulu'ndan etik izin (Tarih:21.04.2016, Protokol No:117) alınd.

\section{Bilgilendirilmiş Onam}

Hasta ve hasta yakınlarının araştırma hakkında açıklama yapılarak bilgilendirilmiş onamları yazılı olarak alındı.

\section{Yazar Katkıları}

Fikir: N.A. Tasarım: E.K., S.Ç Kaynakların toplanması ve/veya işlemesi: N.A. Analiz ve/veya yorum: E.K., N.A Literatür taraması: E.K. Yazıyı yazan: E.K., N.A. Eleştirel inceleme: E.K., S.Ç.,N.A.

\section{Teşekkürler}

Araştırmaya katılan hasta ve hasta yakınlarına teşekkür ederiz.

\section{Çıkar Çatışması Beyanı}

Yazarların herhangi bir çıkara dayalı ilişkisi yoktur.

\section{Araştırma Desteği}

Araştırmayı maddi olarak destekleyen kişi/kuruluş yoktur.

\section{Beyanlar}

$\mathrm{Bu}$ araştırma daha önce herhangi bir kongrede sunulmamıştır.

\section{Kaynaklar}

1. Özşaker E, Okgün Alcan A, Demir Korkmaz F. Yaşlı hastaların yoğun bakım deneyimlerinin incelenmesi. Turkish Journal of Geriatrics. 2013; 16(4):408-413.

2. Adsay E, Dedeli Ö, Yoğun bakım ünitesinden taburcu olan hastaların yoğun bakım deneyimlerinin değerlendirilmesi. Yoğun Bakım Derg. 2015; 6(3): 90-7.

3. Tuna A, Bektaş M, Orhan F, Ayran G, Oyur Çelik G. Koroner yoğun bakımda hasta deneyimleri. Anatol J Clin Investig. 2014;8(2):77-81

4. Özdemir L. Koroner yoğun bakımda kalan hastaların deneyimlerinin belirlenmesi. Hemşirelikte Araştırma Geliştirme Dergisi. 2010; 1:5-12.

5. Obringer K, Hilgenberg C, Booker K. Needs of adult family members of intensive care unit patients, Journal of Clinical Nursing. 2012; 21: 1651-1658.

6. Zaybak A, Yapucu Günes Ü. Hastaların yoğun bakım deneyimlerinin incelenmesi. Ege Üniversitesi Hemşirelik Yüksek Okulu Dergisi 2010;26 (2): 17-26.

7. Demir Y, Korhan E, Eser İ, Khorshid L. Yoğun Bakım Deneyim Ölçeği'nin geçerlik ve güvenirlik çalışması. Türkiye Klinikleri J NursSci. 2009; 1 (1): 1-11.

8. Özgürsoy BN, Durmaz Akyol A. Yoğun bakım ünitesinde yatan hastaların ailelerinin gereksinimleri. Yoğun Bakım Hemşireliği Dergisi. 2008;12(1-2):33-38.

9. Gültekin Y, Özçelik Z, Akıncı SB, Yorgancı HK, Evaluation of stressors in intensive care units. Turk J Surg. 2018; 34: 5-8.

10. Yılmaz E, Arslan S. Acil kritik yoğun bakımda yatan hastaların incelenmesi. Selçuk Tıp Dergisi. 2015; 31(3): 113-117.

11. Ünver $\mathrm{V}$, Yoğun bakım ünitesinde hastası olan ailelerinin gereksinimlerinin saptanması. Yoğun Bakım Hemşireliği Derg. 2003;7(2):75-81.

12. Hashim F, Hussin R. Communication needs of family members with a relative in intensive care unit, Journal of Asian Behavioural Studies. 2012; 2(6).19-28 
13. Frivold G, Slettebø A, Dale B. Family members' lived experiences of everyday life after intensive care treatment of a love done: a phenomenological hermeneutical study. Journal of Clinical Nursing. 2016; 25: 392-402.

14. Gaeeni M, A. Farahani M, Seyedfatemi N, Mohammadi N. Informational support to family members of intensive care unit patients: The perspectives of families and nurses. Global Journal of Health Science. 2015; 7 (2): 8-19

15. Velasco Bueno JM, Alonso-Ovies A, Heras La Calle G, Zaforteza Lallemand C, Main information requests of family members of patients in intensive care units. Med Intensiva. 2018;42(6):337-345. doi: 10.1016/j.medin.2017.09.007.

16. Türkiye İstatistik Kurumu, Hayat Tabloları 2016-2018 http://www.tuik.gov.tr/PreHaberBultenleri.do?id=30712

17. T.C. Sağlık Bakanlığı Sağlık İstatistikleri Yıllığı, 2018. https://dosyasb.saglik.gov.tr/Eklenti/36134,siy2018trpdf.pdf?0

18. Çam R, Şahin B. Yoğun bakım ünitelerinde yatan hastaların deneyimleri ve anksiyete-depresyon durumları. Hemşirelik Bilimi Dergisi. 2018; 1(1):10-14.

19. Çağliyan H, Dağ SG. Kardiyovasküler cerrahi ve koroner yoğun bakım ünitesinden taburcu olan hastaların yoğun bakım deneyimlerinin belirlenmesi. SD ̈U Sağllk Bilimleri Dergisi 2019; 10(4): 349-356.

20. Alasad JA, Abu Tabar N, Ahmad MM. Patients' experience of being in intensive care units. J Crit Care. 2015;30(4):859.e711. doi:10.1016/j.jcrc.2015.03.021.

21. Aktaş Y, Baysan Arabacı L. Yoğun bakımda hasta ve ailesiyle iletişim. İzmir Kâtip Çelebi Üniversitesi Sağllk Bilimleri Fakültesi Dergisi 2016; 1(3): 39-43.

22. Akdemir BN. Hastaların yoğun bakım deneyimleri ve etkileyen faktörlerin belirlenmesi, Gazi Üniversitesi Sağlık Bilimleri Enstitüsü Yüksek Lisans Tezi, Ankara, 2013.

23. Göktas SB, Yildiz T, Nargiz SK, Gur O. A comparison of the intensive care experiences of emergency and elective cardiac surgery patients. Niger J Clin Pract 2016;19:284-9.

24. Keskin AO, Uncu G, Tanburoğlu A, Adapınar DÖ, Yaşlanma ve Yaşlılıkla İlgili Nörolojik Hastalıklar, Osmangazi Tip Dergisi, 2016;38 (Özel Sayı 1): 75-82.

25. Sekmen ID, Ünsar S. Yoğun Bakım Ünitesinde Tedavi Gören Hastaların Deneyimlerinin Belirlenmesi. Turk J Cardiovasc Nurs 2018;9(20):113-119.

26. Mitchell M, Dwan T, Takashima M,et al. The needs of families of trauma intensive care patients: A mixed methods study. Intensive Crit Care Nurs. 2019;50:11-20. doi: 10.1016/j.iccn.2018.08.009.

27. Minton C, Batten L, Huntington A. A multicase study of prolonged critical illness in the intensive care unit: Families' experiences. Intensive Crit Care Nurs. 2019;50:21-27. doi: 10.1016/j.iccn.2018.08.010

28. Hashima F, Hussinb R. Family needs of patient admitted to intensive care unit in a public hospital. Procedia- Social and Behavioral Sciences. 2012; 36: 103- 111. 